\title{
PENGEMBANGAN MODEL APLIKASI ADMINISTRASI PELAYANAN KESEHATAN DI PUSKEMAS DENGAN CLOUD COMPUTING BERBASISKAN OPEN SOURCE
}

\author{
Honni \\ Information Systems Department, School of Information Systems, Binus University \\ Jl. K.H. Syahdan No. 9, Palmerah, Jakarta Barat 11480 \\ honni@binus.edu
}

\begin{abstract}
Puskemas as community health centers becomes one of the main focuses of development on the agenda of the Government of Indonesia beside education. Therefore, we purpose to develop an affordable online system of health care administration based on open source using cloud computing approach. It can be used for collecting data of patients, diseases, and treatment of patients at Puskesmas. The methods used are literature study related to cloud computing, survey design and data collection infrastructure of information technology that can be applied to online health services, analysis of survey data on actual conditions in some centers and other health care centers in Jakarta, then making model of online health services such as physician consulting, prescribing and disease diagnosis. The result is a web-based application system of health care administration of Puskesmas, which utilizes cloud computing technology and development architectures that are both modular and dynamic. The application model combines the benefits of open-source applications with a flexible design system. It also supports mobile devices to improve the quality of patient care. Web-based network structure allows both online and inter-section between institutions which can be accessed anytime, anywhere, through mobile devices. Development application model is also adapted to the function of the business processes and administrative processes that exist in Puskesmas throughout Indonesia. Each model is also expected to be integrated to optimize efficiency and has been adapted to the service system of Dinas Kesehatan and Health Ministery.
\end{abstract}

Keyword: model development, application of health services administration, health centers, cloud computing, open source

\begin{abstract}
ABSTRAK
Puskesmas sebagai pusat pelayanan kesehatan masyarakat dan menjadi salah satu fokus pengembangan utama dalam agenda Pemerintah. Melalui penelitian ini dikembangkan sistem adminstrasi pelayanan kesehatan online berbasiskan open source dengan pendekatan cloud computing, untuk melakukan pendataan pasien, penyakit dan penanganan pasien di Puskesmas dengan biaya yang terjangkau. Metode yang digunakan adalah studi literature berkaitan dengan teknologi cloud computing, survei dan pengumpulan data perancangan infrasruktur teknologi informasi yang dapat diterapkan pada pelayanan kesehatan secara online, analisis data hasil survei terhadap kondisi nyata di beberapa pusat layanan kesehatan khususnya puskesmas di daerah Jabodetabek, dan terakhir membuat model pelayanan kesehatan online dari puskesmas seperti konsultasi dokter, pembuatan resep serta diagnosis penyakit secara online. Hasilnya adalah sistem aplikasi administrasi pelayanan kesehatan di puskesmas berbasis web dengan memanfaatkan teknologi cloud computing serta arsitektur pengembangan yang modular dan dinamis. Model aplikasi ini juga memadukan keunggulan aplikasi berpola open-source dengan desain sistem fleksibel untuk kebutuhan implementasi dan pengembangan, serta dukungan mobile device untuk meningkatkan kualitas pelayanan pasien. Struktur jaringan berbasis web memungkinkan untuk online tidak hanya antar bagian tetapi juga antar instansi dan dapat diakses kapan saja, di mana saja, serta menggunakan perangkat bergerak. Pengembangan model aplikasi juga disesuaikan dengan fungsi proses bisnis dan proses administrasi puskesmas yang ada di seluruh Indonesia. Setiap model juga diharapkan dapat diintegrasikan untuk mengoptimalkan efisiensi dan telah coba disesuaikan dengan sistem pelayanan Dinas Kesehatan dan Kementrian Kesehatan.
\end{abstract}

Kata kunci: pengembangan model, aplikasi administrasi pelayanan kesehatan, puskesmas, cloud computing, open source 


\section{PENDAHULUAN}

Teknologi informasi dan komunikasi sangat bermanfaat dalam mendukung proses bisnis dalam bentuk manajemen data, informasi, fakta, serta pengetahuan, baik itu. Bagi instansi kesehatan seperti rumah sakit, klinik kesehatan, puskesmas, dan lain-lain, salah satu pendukung pentingnya adalah dengan menyediakan aplikasi administrasi pelayanan kesehatan.

Cloud Computing merupakan solusi yang memanfaatkan teknologi komputer dan pengembangan berbasis internet, yang memungkinkan pelanggan menyewa dan memanfaatkan layanan teknologi informasi dan komunikasi dengan pengelolaan infrastuktur, platform maupun aplikasi dilakukan oleh provider, tanpa adanya investasi di sisi pelanggan, sehingga secara keseluruhan memberikan kesederhanaan dan efisiensi. Cloud computing juga merupakan sebuah transformasi dan merupakan bentuk produktifitas di masa depan. Cloud computing adalah terobosan berikutnya yang adadi era internet atau virtual komunikasi.

Bidang kedokteran juga membutuhkan dukungan teknologi yang memadai termasuk juga teknologi informasi berbasis cloud computing. Seperti halnya pengembangan "telemedicine", yaitu pelayanan di bidang kesehatan jarak jauh. Ini berarti layanan pengobatan yang mencakup semua bentuk pengobatan yang memanfaatkan media, di mana pasien dan dokter dapat berkomunikasi jarak jauh, baik menggunakan telepon seluler, telepon rumah, internet dan sebagainya. telemedicine juga didefinisikan sebagai transfer data medis elektronik dari satu lokasi ke lokasi lainnya secara online.

Telemedicine bisa dikatakan sebagai alat yang dapat membantu banyak orang dengan beragam masalah kesehatan. Sangat banyak manfaat yang ditawarkan dalam penggunaan telemedicine, seperti halnya efektivitas waktu, biaya dan tenaga. Artinya, pasien tidak perlu untuk jauh-jauh datang ke rumah sakit yang menghabiskan banyak waktu di perjalanan, biaya bahan bakar, dan fisik bertahan di tengah-tengah kemacetan untuk berkonsultasi masalah kesehatan dengan dokter. Pasien cukup memanfaat teknologi informasi seperti halnya email atau bahkan video conference dan lain sebagainya untuk mendapatkan layanan kesehatan. Manfaat lain yang ditawarkan yaitu mengatasi persebaran tenaga medis atau ahli kesehatan, dokter yang sudah professional yang persebarannya tidak merata disetiap daerah yang ada di Indonesia. Intinya, dengan telemedicine (telemedika), pasien dapat berkonsultasi dan melakukan pengobatan jarak jauh dengan dokter ahli yang ia percayai mampu untuk membantu permasalahannya.

Banyaknya masalah dan tantangan dalam pelayanan kesehatan masyarakat di Indonesia, justru dapat memberikaan peluang menarik untuk melakukan pengembangan sistem e-health yang dapat membantu pemecahan masalah tersebut. Beberapa contoh masalah misalnya adalah: belum meratanya kuantitas dan kualitas pelayanan kesehatan, masih relatif tingginya angka kematian ibu melahirkan dan bayi, berbagai masalah dalam penanganan pasien tuberculosis, dan penyakit lainnya.

Untuk menurunkan angka kematian ibu, bayi dan balita, telah diusulkan dan dilakukan berbagai usaha oleh banyak instansi/lembaga dan/atau kelompok, terutama di bawah koordinasi departemen kesehatan. Kelompok Teknik Biomedika telah sejak sekitar tahun 1997 memfokuskan pada penelitian dalam sistem telemedika (ICT-based telemedicine System). Penggunaan sistem telemedika berbasis teknologi komunikasi dan informasi dalam pelayanan kesehatan masyarakat, yang dilakukan secara bertahap dan berkelanjutan, diharapkan secara bertahap dapat menurunkan angka kematian ibu, bayi dan balita di Indonesia.

Telemedika merupakan aplikasi teknologi elektronika, komputer dan telekomunikasi dalam teknik biomedika, untuk melakukan pertukaran informasi kedokteran dari satu tempat ke tempat lain, guna membantu pelaksanaan prosedur kedokteran, dengan tujuan meningkatkan kualitas hidup 
manusia melalui peningkatan pelayanan kesehatan masyarakat. Dengan demikian, dalam sistem telemedika selalu dilakukan pemrosesan informasi kedokteran dan pengiriman dan penerimaan informasi kedokteran, serta hasilnya harus menunjang pelaksanaan prosedur kedokteran.

Seiring dengan kemajuan pesat dalam teknologi pendukungnya, dalam beberapa tahun terakhir ini, telah terjadi perkembangan yang sangat pesat dalam telemedika dan e-health. Perkembangan yang sangat pesat dalam sistem telekomunikasi bergerak (wireless mobile telecommunication) dan sistem telekomunikasi satelit, serta tersedianya infrastruktur yang disediakan oleh berbagai penyelenggara jaringan telekomunikasi, telah memungkinkan pengembangan berbagi jenis mobile telemedicine systems dan m-health systems. Kemajuan dalam teknologi pendukung, termasuk perangkat keras dan perangkat lunak komputer telah mendorong berbagai pengembangan sistem telemedika dan $e$-health untuk berbagai jenis aplikasi.

Sebagai suatu bidang yang bersifat multidisiplin, teknik biomedika (Biomedical Engineering) menerapkan berbagai metoda engineering dan sains dalam bidang biologi dan kedokteran untuk memproses berbagai jenis informasi kedokteran, guna membantu pelaksanaan prosedur kedokteran agar dapat meningkatkan kualitas hidup manusia melalui peningkatan pelayanan kesehatan masyarakat. Bidang multidisiplin ini memerlukan kerjasama sinergis banyak bidang-bidang terkait, seperti: elektronika dan mikroelektronika, komputer, telekomunikasi, informatika, teknik mesin, fisika, biologi, kedokteran, bahkan bidang ekonomi, hukum, etika dan agama. Beberapa contoh informasi kedokteran, adalah teks alfanumerik, sinyal fisiologis (bio-signals), bunyi dan suara, citra (images) yang bersifat statik atau dinamik, serta berbagai kombinasinya.

Dengan jumlah puskesmas di seluruh Indonesia lebih dari 8600 buah yang diperkirakan melayani lebih dari 50\% penduduk, tantangan (dan peluang) penggunaan e-health dan telemedika dalam membantu memecahkan masalah pelayanan kesehatan masyarakat menjadi makin besar.

Oleh karena itu dalam penelitian ini akan dikembangkan aplikasi telemedika dan e-health dengan pendekatan cloud computing yang berbasiskan open source yang efektif dan efisien sehingga dapat diimplementasikan untuk menangani administrasi kesehatan di puskesmas yang tersebar di berbagai wilayah di Indonesia.

Penelitian ini dikembangkan dengan tujuan (competitive advantages): (1) mendapatkan bisnis plan untuk pengembangan infrastruktur sistem administrasi pelayanan kesehatan yang berbasiskan open source dengan pendekatan cloud computing yang efektif dan efisien; (2) membuat aplikasiaplikasi pendukung sistem administrasi pelayanan kesehatan yang dapat diterapkan di Puskesmas seperti pencatatan dan pelaporan data pasien, basisdata pelayanan kesehatan, konsultasi kesehatan jarak jauh dan pembelajaran bagi masyarakat dan petugas kesehatan dalam bentuk managemen pengetahuan dan repository berbasiskan open source program; (3) mendapatkan model pelayanan kesehatan masyarakat untuk penanggulangan penyakit menular seperti TBC, Kanker dan lain-lain; (4) mendapatkan model-model pelayanan kesehatan jarak jauh yang berbasiskan cloud computing seperti onlinekonsultasi, online diagnosis sederhana, online-reporting, pengelolaan wabah penyakit terdistribusi, mobile telemedika, dan real-time monitoring kondisi pasien secara online; (5) membuat rekomendasi pelayanan kesehatan berbasiskan open source secara online yang efektif dan efisien khususnya yang dapat diaplikasikan pada Puskesmas atau rumah sakit yang terpencil.

Manfaat yang dapat diperoleh dari dari penelitian ini adalah: (1) mendapatkan gambaran umum dan permasalahan yang dihadapi dalam pelayanan kesehatan masyarakat di Puskesmas dan kemungkinan pengembangan pelayanan kesehatan secara online menggunakan pendekatan cloud computing; (2) tersedianya sistem aplikasi kesehatan online yang dapat diterapkan di Puskesmas sehingga dapat meningkatan pelayanan kesehatan kepada masyarakat dengan investasi yang relatif rendah; (3) menjadi media pembelajaran bagi masyarakat dalam menjaga kesehatan dan pengenalan berbagai penyakit dan pencegahannya kepada setiap lapisan masyarakat tanpa batas waktu dan tempat; 
(4) tersedianya acuan standard bagi instansi pemerintah ataupun swasta dalam mengembangkan aplikasi online pelayanan kesehatan yang berkaitan dengan konsultasi online, resep elektronik, diagnosis penyakit secara online dan dokter online yang andal; (5) menjadi media penelitian untuk mendukung pembelajaran matakuliah rekayasa perangkat lunak, computer vision, machine learning dan e-application serta mengaktifkan kegiatan Riset Group Bioinformatika di Universitas Bina Nusantara.

\section{METODE}

Pada penelitian ini akan dikembangkan sistem adminstrasi pelayanan kesehatan online berbasiskan open source dengan pendekatan cloud computing, sehingga dapat digunakan untuk melakukan pendataan pasien, penyakit dan penanganan pasien di Puskesmas dengan biaya yang relative terjangkau. Hal-hal yang dilakukan dalam penelitian ini adalah sebagai berikut: studi literatur yang berkaitan dengan teknologi cloud computing, survei dan pengumpulan data perancangan infrasruktur teknologi informasi yang dapat diterapkan pada pelayanan kesehatan secara online, analisis data hasil survei terhadap kondisi nyata di beberapa pusat layanan kesehatan khususnya puskesmas di daerah Jabodetabek, selanjutnya membuat model palayanan kesehatan online dari puskesmas seperti konsultasi dokter, pembuatan resep serta diagnosis penyakit secara online. Kemudian dibuat sistem aplikasi pelayanan kesehatan masyarakat online di puskesmas. Di samping itu dalam tahap ini juga akan dikembangkan sistem secara modul untuk lebih memudahkan pengambangan aplikasi lebih lanjut dan memudahkan implementasinya di tempat yang berbeda.

Langkah-langkah yang dilakukan dalam penelitian ini adalah: (1) studi literatur dan pencarian data dan informasi di internet - hal ini dilakukan untuk mendapatkan informasi terkini mengenai perkembangan metode dan model pelayanan kesehatan online di puskesmas dan rumah sakit atau dari dokter spesialis; (2) pengumpulan data dan survei lapangan - kegiatan ini dilakukan dengan dua cara yaitu survai langsung terhadap puskesmas di wilayah jabodetabek dan penyebaran kuisioner terhadap pasien untuk mendapatkan data metode kondisi penyakit dan tingkat layanan dari suatu pelayanan kesehatan sehingga diperoleh gambaran kondisi di lapangan; (3) analisis data dan pemodelan sistem dilakukan untuk menganalisis data yang telah terkumpul dengan menggunakan metode statistik untuk mendapatkan parameter-parameter pemodelan sistem, baik yang dikembangkan secara terstruktur ataupun yang dikembangkan dengan metode yang berorientasi objek; (4) formulasi model dan perancangan system - dilakukan dengan untuk mendapatkan kebutuhan user dan kebutuhan system secara functional dan non functional serta design system, dalam hal ini akan dirumuskan keterkaitan antara studi literatur dan konsisi lapangan sehingga diperoleh model yang cukup valid; (5) implemantasi sistem, dimaksudkan untuk membuat prototype dari model system yang telah dibuat sehingga diperolah aplikasi-aplikasi layanan kesehatan secara online yang dikembangkan secara modular; (6) testing dan evaluasi sistem - pengujian dilakukan terhadap system aplikasi dan model yang dikembangkan dengan data real untuk memvalidasi model.

\section{Tahap Pertama: Pengembangan Model Layanan Puskesmas Online}

Pada tahap ini akan dilakukan pengembangan model layanan puskesmas secara online yang meliputi pengembangan database pelaporan dan koordinasi terhadap data pasien, data obat, data penyakit dan data operasional puskesmas yang dikemas dengan database berbasis web dengan pendekatan open source programming. Dalam system ini dapat digunakan untuk membuat laporan periodik dari layanan puskesmas sehingga setiap layanan puskesmas pada suatu daerah dapat dimonitor oleh pemerintah pusat ataupun daerah secara cepat. Dalam tahapan ini juga akan dikembangkan strategi infrastruktur teknologi informasi yang tepat untuk dapat melakukan pelayanan kesehatan masyarakat secara online di puskesmas. Pengembangan strategi IT tersebut menggunakan 
pendekatan cloud computing dengan bernasiskan open source. Dengan konsep tersebut diharapkan dapat digunakan untuk melokalisir adanya wabah penyakit menular di suatu daerah, karena prosesnya dapat diketahui secara lebih dini, sehingga dapat ditangani secara lebih efisien.

\section{Tahap Kedua: Pengembangan Model Konsultasi Kesehatan Online}

Pada tahap ini akan dikembangkan model system konsultasi kesehatan secara online dengan memberlakukan konsep resep elektronik dan mobile computing untuk dapat melakukan pembelajaran kesehatan kepada setiap lapisan masyarakat dengan tingkat informasi yang sama baik ke pusat ataupun daerah. Dengan konsep ini juga dapat memberikan kemudahan terhadap puskesmas yang memiliki keterbatasan dokter, karena ketersediaan dokter dapat diwakilioleh suatu system yang dapat memberikan jawaban secara otomatis terhadap problema kesehatan dari pasien. Untuk memfokuskan penelitian pada tahap ini akan dikembangkan system konsultasi online terhadap beberapa penyakit yang sering terjadi di masyarakat seperti darah tinggi, diabetes, demam berdarah, TBC dan beberapa penyakit menular kritis lainnya. Selain itu konsultasi online dapat dikembangkan juga ke konsultasi psikologi dan konsultasi kesehatan ibu dan anak.

\section{Tahap Ketiga: Pengembangan Model Diagnosis Penyakit Secara Online}

Pada tahap ini akan dilakukan pembuatan sistem yang dapat melakukan diagnosis penyakit secara online atau jarak jauh serta system yang dapat melakukan monitoring terhadap data pasien secara real time sepanjang waktu sehingga dapat mengetahui konsidi perkembangan pasien secara lebih akurat. Beberapa metode yang digunakan dalam menembangkan model diagnosis penyakit adalah dengan pendekatan pengenalan pola citra digital dan pembelajaran mesin. Hasil yang diharapkan dalam tahap ini adalah adanya suatu system yang dapat mendiagnosa pasien secara online dengan menggunakan teknologi cloud computing. Selain itu juga dapat dihasilkan beberapa alat bantu diagnose portable yang mudah digunakan oleh pasien.

\section{HASIL DAN PEMBAHASAN}

\section{Studi Literatur}

\section{State of the art}

Teknik biomedika mempunyai banyak bidang cakupan yang sangat luas, termasuk telemedika dan e-health. Sejumlah bidang cakupan lain misalnya adalah: instrumentasi biomedika, bioinformatika, medical informatics, artificial intelligence, biomekanika, biomaterials, tissue engineering, prostheses \& artificial organs, biomedical imaging \& image processing, assistive technology \& rehabilitation engineering, serta drug delivery system.

Sejumlah aplikasi sistem telemedika puskesmas yang telah dibahas, memerlukan pengembangan modul perangkat lunak untuk menunjang berbagai jenis aplikasi. Misalnya: aplikasi pencatatan dan pelaporan data pasien dan data obat, evaluasi tingkat gizi balita, serta sistem telekonsultasi sederhana. Selain pengembangan modul perangkat lunak, telah pula dilakukan sejumlah pengembangan modul perangkat keras. Beberapa contoh adalah: timbangan elektronik berbasis PC untuk dewasa dan balita, EKG berbasis PC atau mikrokontroler, Pengukur Tekanan Darah berbasis PC atau mikrokontroler, Audiometer berbasis PC. Alat-alat berbasis PC tersebut memerlukan interface perangkat keras dan perangkat lunak yang khusus dibuat. Selain itu, telah dikembangkan paket perangkat lunak khusus untuk pengelolaan peralatan kedokteran di rumahsakit. Perangkat lunak 
tersebut telah di-instalasi di Rumahsakit Hasan Sadikin Bandung, dan Rumahsakit Permata Hati Banda Aceh. (Soegijoko, Irawan, \& Sutjiredjek, 2006).

Penyampaian pelayanan-kesehatan melalui jarak jauh bidang kesehatan dan keperawatan merupakan salah satu alternative pelayanan kesehatan masyarakat yang perlu dikembangkan pada era globalisasi saat ini. Penggunaan telemedika bersifat multidisiplin, menerapkan teknologi elektronika, komputer, telekomunikasi, serta instrumentasi, untuk transfer informasikedokteran dari satu tempat ke tempat lain dalam membantu pelaksanaan prosedur kesehatan. Pengamatan terhadap perkembangan telemedika di seluruh dunia menunjukkan bahwa aplikasinya untuk kesehatan masyarakat lebih berpengaruh pada negara berkembang, namun tingkat kegagalannya cukup konsisten dalam akseptabilitas dan keberlangsungannya sebagai akibat kekurang-siapan organisasi kesehatan untuk menerima perubahan serta faktor lain yang sejak semula tidak mendukung keberlangsungannya. Pengembangan konsep sistem telemedika masyarakat berbasis ICT yang mengutamakan efektifitas, akseptabilitas dan keberlangsungan dari penerapan sistem secara nyata masih perlu dipikirkan dengan aplikasi yang sederhana.

\section{Beberapa Kegiatan yang Dilakukan}

Penggunaan telemedika dan $e$-health sangat luas dan mengalami perkembangan yang sangat pesat. Hal ini dapat diamati dari sejumlah besar publikasi ilmiah dalam telemedika, e-health, dan bidang-bidang terkait lainnya, yang dipresentasikan dalam sejumlah banyak pertemuan ilmiah dan/atau dimuat pada berbagai majalah atau proceedings. Berbagai contoh organisasi profesi terkait adalah: International Society for telemedicine and eHealth (ISfTeH), Institute for Electrical and Electronics Engineers Inc. - Engineering in Medicine and Biology Society (IEEE - EMBS), IEEE Circuits and Systems Society (IEEE - CASS), American telemedicine Association (ATA), serta Masyarakat Biomedika Indonesia (MBI). Selain itu, sejumlah pertemuan ilmiah regular telah diselenggarakan di berbagai negara, seperti misalnya: Asia Pacific Telecommunity (APT) Regional Workshop on telemedicine, APEC e-Health Seminar, Med-e- Tel, dan BME Days. Beberapa contoh jurnal dalam bidang telemedika dan ehealth misalnya: Journal of telemedicine and Telecare, telemedicine and e-Health, Journal of eHealth Technology and Application, eHealth International Journal, International Journal of E-Health and Medical Communications.

Beberapa kegiatan yang saat ini sedang dan akan dilakukan adalah sebagai berikut: (1) sistem telemedika untuk aplikasi dalam bidang Opthalmologi (tele-opthalmologi); (2) sistem telemedika untuk aplikasi dalam bidang dermatologi (tele-dermatologi); (3) penggunaan biometrika sidik jari dalam pencatatan dan identifikasi data pasien (untuk puskesmas dengan jumlah pasien per hari di atas 100 orang); (4) pengembangan sistem resep elektronik untuk puskesmas; (5) sistem telemedika bergerak dengan multi communication links untuk rumah sakit; (6) istem telemedika berbasis ICT untuk pengelolaan kejadian luar biasa (wabah); (7) sistem telemedika berbasis ICT untuk pengelolaan masalah pelayanan kesehatan masyarakat (misal: penyakit TBC, lepra); (8) sistem telemedika berbasis ICT untuk pengelolaan masalah pelayanan UGD.

\section{Telemedika dan e-Health}

Telemedika (telemedicine) dan e-health merupakan dua bidang cakupan teknik biomedika, yang juga bersifat multidisiplin. Istilah telemedika kebetulan telah diperkenalkan lebih awal dibandingkan dengan istilah $e$-health, namun sebenarnya telemedika adalah bagian (sub-set) dari $e$ health. Selain itu terdapat pula istilah telehealth. Ada sejumlah definisi yang telah digunakan untuk menjelaskan telemedika, e-health dan tele-health (Wootton, Patil, Scott, \& Ho, 2009). Sebagai salah satu bidang dalam ruang - lingkup teknik biomedika, telemedika (telemedicine) dapat diartikan sebagai penggunaan teknologi informasi dan komunikasi (termasuk pula elektronika, tele-komunikasi, komputer, informatika) untuk men-transfer (mengirim dan/atau menerima) informasi kedokteran, guna meningkatkan pelayanan klinis (diagnosa dan terapi) serta pendidikan. Kata "tele" dalam bahasa 
Yunani berarti: jauh, pada suatu jarak, sehingga telemedika dapat diartikan sebagai pelayanan kedokteran melalui suatu jarak. Selain telemedicine, diperkenalkan pula istilah telehealth yang sangat berdekatan artinya. telehealth diartikan sebagai penggunaan teknologi informasi dan komunikasi (elektronika, telekomunikasi, komputer, informatika) untuk mengirimkan dan/atau menerima informasi kedokteran dan pelayanan kesehatan, guna meningkatkan pelayanan klinis (diagnosa dan terapi), administrasi serta pendidikan. Dalam pelayanan administrasi termasuk pula pengiriman informasi operasional, demografi, yang mungkin tidak terlalu terkait dengan masalah klinis. Istilah Telecare diartikan sebagai penggunaan teknologi informasi dan komunikasi (termasuk pula elektronika, telekomunikasi, komputer, informatika) untuk men-transfer (mengirim dan/atau menerima) informasi kedokteran, guna melakukan pelayanan klinis (terutama diagnose dan terapi) kepada pasien atau sejumlah pasien di tempat tinggal mereka. Sering pula digunakan istilah home telecare atau tele-homecare. e-Health (electronic Health) adalah penggunaan teknologi informasi dan komunikasi (termasuk pula elektronika, telekomunikasi, komputer, informatika) untuk memproses (dalam arti yang luas) berbagai jenis informasi kedokteran, guna melaksanakan pelayanan klinis (diagnosa dan terapi), administrasi serta pendidikan. Dalam $e$-health, faktor jarak tidak dipersoalkan, artinya: e-health mencakup pula telemedika, tele-health, maupun pelayanan kesehatan dalam satu lokasi yang sama.

\section{Penggunaan FOSS / FLOSS dalam e-Health}

Mengingat biaya sistem e-health dan telemedika yang dapat menjadi mahal, makin banyak usaha pengembangan sistem dengan menggunakan Free and Open Source Software (FOSS, FLOSS). Dengan tujuan untuk menghasilkan sistem $e$-health yang relatif murah, kecenderungan pengembangan dan penggunaan sistem e-health berbasis free and open source software makin meningkat. Guna memperoleh sejumlah manfaat dan mempersingkat waktu pengembangan sistem e-health, berbagai upaya dan usaha kerjasama antar sejumlah lembaga dapat dan/atau telah dilakukan. Mengapa telemedika dan $e$-health dipergunakan, dan apa pula manfaatnya?

Mengacu pada "Proceedings of APEC e-Health Seminar 2008", terdapat 10 manfaat yang diharapkan dari penggunaan sistem e-health: (1) peningkatan efisiensi, penurunan biaya; (2) peningkatan kualitas pelayanan kesehatan; (3) pembuktian melalui evaluasi ilmiah (evidence based); (4) pemberdayaan pasien dan konsumen; (5) mendorong terjadinya hubungan yang lebih baik antara pasien dan tenaga kesehatan; (6) pendidikan bagi tenaga kesehatan dan pendidikan bagi masyarakat; (7) mendorong tumbuhnya komunikasi dan pertukaran informasi antar lembaga pelayanan kesehatan; (8) perluasan ruang-lingkup pelayanan kesehatan; (9) masalah etika (practice, informed consent, privacy, equity); (10) masalah kesetaraan (pelayanan kesehatan bagi seluruh masyarakat).

Namun demikian, manfaat yang menjadi alasan pemanfaatan sistem telemedika dan $e$-health dapat sangat berbeda antara negara maju dan Negara berkembang. Sistem telemedika dan e-health dapat pula memungkinkan dilaksanakannya pelayanan kesehatan, yang tidak mungkin terlaksana tanpa tersedianya sistem telemedika atau sistem $e$-health tertentu.

\section{Sistem Telemedika Puskesmas}

Sistem e-health/telemedika puskesmas ini pada dasarnya terdiri atas sejumlah "terminal" (stasiun medis) berupa sejumlah PC berikut paket perangkat lunak yang sesuai dengan fungsi system yang dikehendaki, serta dihubungkan dengan suatu jaringan lokal (LAN) dan/atau global (misalnya jaringan internet). Suatu puskesmas dapat mempunyai sistem $e$-health yang terdiri atas sebuah stasiun medis, atau sampai ke suatu system $e$-health/telemedika yang terdiri atas sejumlah stasiun medis. Fungsi-fungsi yang dapat dilakukan misalnya adalah: pencatatan dan pelaporan, telekonsultasi, telekoordinasi, tele-diagnosis sederhana (Soegijardjo, 2009). Paket perangkat lunak yang diperlukan (digunakan) sangat bervariasi, tergantung pada fungsi sistem yang dikehendaki. Sistem telemedika/e- 
health puskesmas ini dapat dikembangkan menjadi sistem e-health/telemedika untuk klinik atau rumahsakit kecil.

Roadmap penelitian yang sudah dan akan dilaksanakan dalam penelitian ini, dapat dilihat pada Gambar 1 di bawah ini:

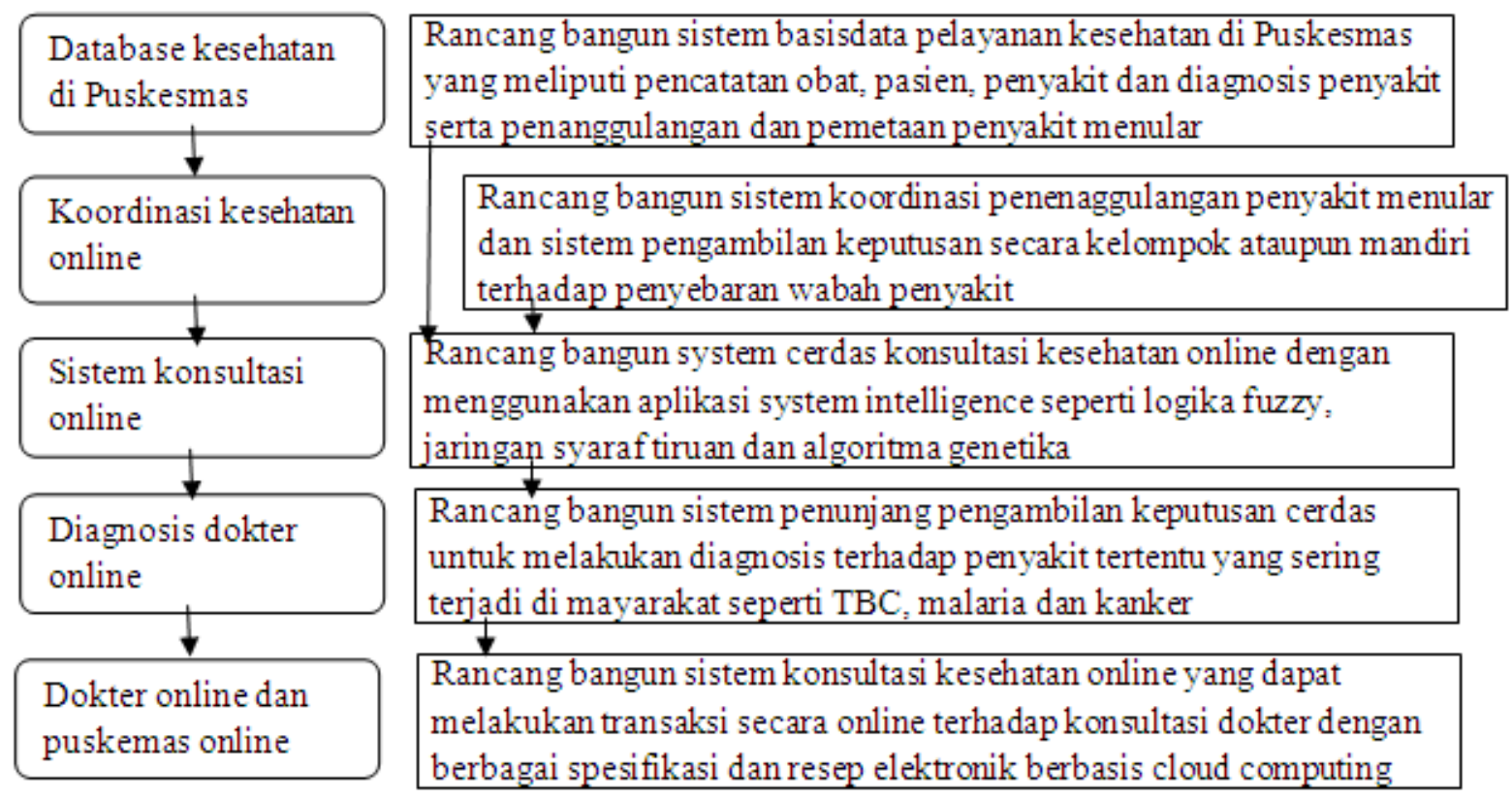

Gambar 1 Roadmap penelitian

\section{Pengembangan Model}

Pemanfaatan SaaS (Software as a Service) dipilih dalam pengembangan model aplikasi administrasi pelayanan kesehatan di puskemas berbasiskan open source karena teknologi ini memiliki karakteristik layanan yang memberikan manfaat seperti disisi efisiensi biaya operasional terutama pada puskesmas. Dengan komputasi awan puskesmas tidak perlu melakukan pengembangan, pembelian, pemeliharaan dan pengamanan perangkat lunak dan keras serta sistem operasi karena sudah dilakukan secara virtual oleh penyedia layanan tersebut, termasuk proses keterkiniannya. Beberapa manfaat yang diperoleh antara lain (1) Penghematan biaya, penggunaan teknologi ini menghemat biaya karena menggunakan anggaran yang rendah untuk sumber daya dari puskesmas dan juga membantu dalam menekan biaya operasi yang dikeluarkan oleh puskesmas dalam rangka meningkatkan reliability dan kritikan sistem yang dibangun. (2) Peningkatan kapasitas penyimpanan, puskesmas yang menggunakan teknologi ini dapat menyimpan data lebih banyak dibandingkan pada komputer pribadi. (3) Mudah diotomatisasi seorang pengembang tidak perlu khawatir terhadap perangkat lunak atau aplikasi administrasi pelayanan kesehatan di puskesmas agar tetap up-to-date. (4) Fleksibel, teknologi ini menawarkan lebih banyak fleksibilitas, contohnya dalam hal virtualisasi, dari metode komputasi sebelumnya dan dengan mudah dapat berorientasi pada profit dan perkembangan yang cepat berubah. (5) Mobilitas yang lebih, puskesmas yang mempunyai pegawai/pengguna dapat mengakses informasi di manapun berada. Cloud dapat membuat manejemen dan operasional lebih mudah karena masyarakat atau puskesmas terkoneksi dalam satu cloud sehingga dapat dengan mudah untuk memonitor dan mengaturnya. (6) Mengubah titik fokus, puskesmas tidak perlu lagi mengkhawatirkan server yang harus di-update dan isu komputasi lainnya, sehingga dapat fokus pada hal lain. 
Pengembangan model aplikasi administrasi pelayanan kesehatan di puskemas dengan cloud computing berbasiskan open source dapat dilihat pada Gambar 2 berikut ini:

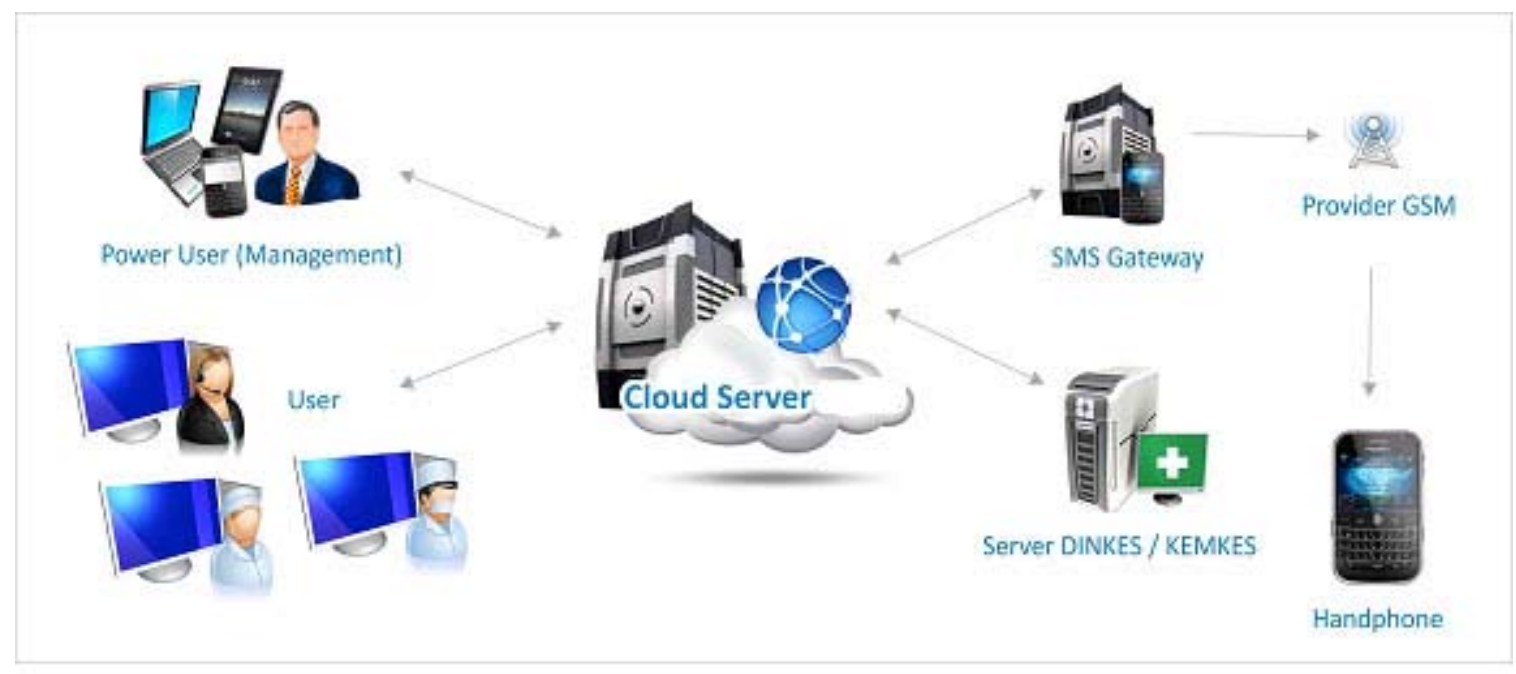

Gambar 2 Pengembangan Model

Model aplikasi pada penelitian ini merupakan aplikasi sistem informasi yang digunakan untuk pelayanan kesehatan di puskesmas diharapkan terutama dalam lingkup yang luas dan komprehensif. Dikembangkan berbasis web dengan memanfaatkan teknologi cloud computing serta arsitektur pengembangan yang bersifat modular dan dinamis. Model aplikasi ini juga memadukan keunggulan aplikasi berpola open-source dengan desain sistem yang fleksibel untuk kebutuhan implementasi dan pengembangan, serta mendukung mobile device untuk meningkatkan kualitas pelayanan pasien.Struktur jaringan yang berbasis web memungkinkan untuk online tidak hanya antar bagian tetapi juga antar instansi dan dapat diakses kapan saja, di mana saja, serta menggunakan perangkat bergerak. Protokol komunikasi yang tersedia dirancang dengan tingkat keamanan yang tinggi untuk memastikan tingkat kerahasiaan data. Setiap pasien selalu mengharapkan pelayanan yang terbaik dan profesional dari seorang ahli, dan tentunya diharapkan pula dengan harga yang terjangkau untuk segala lapisan masyarakat. Pengembangan model aplikasi juga disesuaikan dengan fungsi proses bisnis dan proses administrasi puskesmas yang ada di seluruh Indonesia. Hal ini dapat memperingkas proses kerja dan menghindari overhead akibat fitur-fitur yang sebenarnya tidak diperlukan. Setiap model juga diharapkan dapat diintegrasikan untuk mengoptimalkan efisiensi dan telah coba disesuaikan dengan sistem pelayanan Dinas Kesehatan dan Kementrian Kesehatan.

\section{PENUTUP}

Data dalam penelitian ini disusun setiap kali seorang pasien memperoleh layanan kesehatan dari sebuah bagian di puskesmas, misalnya radiologi, laboratorium, farmasi; atau berdasarkan hasil kegiatan administratif, misalnya klaim asuransi. Dalam sistem kesehatan yang telah ada secara umum, pasien dan petugas kesehatan berhadapan dengan data melalui aplikasi yang tersedia untuk setiap bagian tersebut secara terpisah.

Pertukaran data antar bagian, bila diperlukan, masih berdasarkan catatan kertas yang diantar dari satu bagian ke bagian lain diharapkan sudah tidak terjadi lagi dengan adanya penelitian ini. 
Arsitektur sistem pencatatan kesehatan yang terstruktur dapat dikelola oleh sistem ini dan memungkinkan data digunakan bersama dalam sistem. Komponen utama dari sistem ini adalah: (1) komponen administratif, (2) komponen laboratorium, (3) komponen radiologi, (4) komponen farmasi, (5) input order dokter, serta (6) dokumentasi klinis.

\section{DAFTAR PUSTAKA}

Soegijoko, S., Irawan, Y. S., \& Sutjiredjek, E. (2006). Sistem telemedika berbasis teknologi informasi \& komunikasi untuk pelayanan kesehatan masyarakat di indonesia. Prosiding Konferensi Nasional Teknologi Informasi \& Komunikasi untuk Indonesia, 3 - 4 Mei 2006.

Soegijoko, Soegijardjo. (2009). ICT applications in e-health: improving community healthcare services towards achieving the MDGs. United Nations Roundtable on 'Governance and Applications of ICT for Achieving the MDGs', The United Conference Centre, Bangkok (Thailand), 9 - 10 December 2009.

Soegijoko, Soegijardjo. (2010) Perkembangan terkini telemedika dan e-health serta prospek aplikasinya di Indonesia. Proceeding Seminar Nasional Aplikasi Teknologi Informasi (SNATI), 2010, ISSN: 1907-5022

Wootton, R., N.G. Patil, R.E. Scott, and K. Ho. (2009) Telehealth in the Developing World. London: IDRC - Royal Society of Medicine Press. 